Prepared for the U.S. Department of Energy under Contract DE-AC05-76RL01830

\title{
Retention of Halogens in Waste Glass
}

\author{
P Hrma
}

May 2010

\section{Pacific Northwest}

NATIONAL LABORATORY

Proudly Operated by Battelle Since 1965 


\section{Retention of Halogens in Waste Glass}

P Hrma

May 2010

Prepared for

the U.S. Department of Energy

under Contract DE-AC05-76RL01830

Pacific Northwest National Laboratory

Richland, Washington 99352 


\section{Summary}

In spite of their potential roles as melting rate accelerators and foam breakers, halogens are generally viewed as troublesome components for glass processing. Of five halogens, F, Cl, Br, I, and At, all but At may occur in nuclear waste. A nuclear waste feed may contain up to $10 \mathrm{~g}$ of F, $4 \mathrm{~g}$ of Cl, and $\leq 100 \mathrm{mg}$ of $\mathrm{Br}$ and I per $\mathrm{kg}$ of glass. The main concern is halogen volatility, producing hazardous fumes and particulates, and the radioactive ${ }^{129} \mathrm{I}$ isotope of $1.7 \times 10^{7}$-year half life. Because $\mathrm{F}$ and $\mathrm{Cl}$ are soluble in oxide glasses and tend to precipitate on cooling, they can be retained in the waste glass in the form of dissolved constituents or as dispersed crystalline inclusions.

This report compiles known halogen-retention data in both high-level waste (HLW) and low-activity waste (LAW) glasses. Because of its radioactivity, the main focus is on I. Available data on $\mathrm{F}$ and $\mathrm{Cl}$ were compiled for comparison. Though $\mathrm{Br}$ is present in nuclear wastes, it is usually ignored; no data on $\mathrm{Br}$ retention were found.

Reporting on decontamination factors for halogens from HLW processing began in nineteen eighties, starting with the pilot-scale melter PSCM-22 (1986) and continued with several other melter tests, PSCM23 (1990), LFCM-8 (1994), and SSHTM-3 (1994). The F retention was found relatively stable at 75 $\pm 9 \%$, whereas the $\mathrm{Cl}$ retention varied from $75 \%$ to $85 \%$. Only in PSCM-22 test, retention values for I were determined based on chemical analysis of glass, resulting in a value of $8 \%$, which was lower than the value from the off-gas analysis $(23 \%)$.

Because halides are water soluble, they mostly partition to the LAW portion in waste pretreatment. Therefore, from nineteen nineties onwards crucible studies were performed and melter tests were evaluated with respect to the halogen retention in LAW glasses.

Li et al. (1995) melted borosilicate LAW glasses at temperature $1300^{\circ} \mathrm{C}$ to $1450^{\circ} \mathrm{C}$. The excess of $\mathrm{F}$ above the solubility limit formed $\mathrm{CaF}_{2}$ and $\mathrm{NaF}$ crystals and the excess $\mathrm{Cl}$ formed spherical $\mathrm{NaCl}$ inclusions (crystallized $\mathrm{NaCl}$ droplets). In 1996, Feng et al. found that LAW glasses heated for $2 \mathrm{~h}$ at 1130 to $1380^{\circ} \mathrm{C}$ with $4-9 \% \mathrm{CaO}$ retained $100 \%$ of $\mathrm{F}$, whereas glasses with $\leq 2 \% \mathrm{CaO}$ retained only $85 \%$ and $77 \% \mathrm{~F}$. The retention of $\mathrm{Cl}$ was $0.52 \pm 0.14 \%$. Crichton et al. (1995) observed that $\mathrm{F}$ and $\mathrm{Cl}$ volatilized from the melt surface, but excess $\mathrm{Cl}$ separated into liquid $\mathrm{NaCl}$ inclusions that rose to the melt surface by buoyancy, where they made a segregated evaporating layer. Iodine created gaseous $\mathrm{I}_{2}$ bubbles that rose to the melt surface, where they burst. In addition, iodine evaporates from the feed before it becomes glass.

According to by Whyatt et al., who compiled and evaluated various LAW vitrification tests in 1996, about $50 \%$ of $\mathrm{Cl}$ and $20 \%$ of I were retained in the glass processed by feeding slurry into a continuous Joule-heated melter. In 2002 and 2003, Matlack et al. and Lee André reported data on the retention of halogens in DuraMelter 100 containing $115-120 \mathrm{~kg}$ of glass, possessing the melt surface area of 0.108 $\mathrm{m}^{2}$, and operating at the average melt temperature of $1150^{\circ} \mathrm{C}$. Both glass offgas were analyzed. The $\mathrm{F}$ retention was consistently high (94\%) and the $\mathrm{Cl}$ retention was $\sim 60 \%$, regardless the glass composition and the targeted halogen content. The targeted fraction of I was 0.1 mass $\%$ for all tests and the analyzed fractions of I in glass varied from $<0.01$ to 0.04 mass $\%$, resulting in retention values of $23 \pm 10 \%$. When the melter was idled for 2 months, the $\mathrm{Cl}$ concentration in glass dropped from 0.0022 to 0.0009 . Also, the $\mathrm{Cl}$ retention decrease by $\sim 1 \%$ for every $1-\mathrm{L} / \mathrm{min}$ increase in bubbling. 
Generally, provided that the melter type and melting conditions are equal, the retention ratios of halogens linearly decrease with the halogen ionic radii and increase with the sodium halide melting temperatures, even though, as Crichton et al. observed, different mechanism of liberation from glass operates for different halogens.

Crucible studies are unreliable as predictors for the retention of halogens in continuous melters. Consistent data are obtainable during the normal mode of melter operation. These data vary little with glass composition within the LAW composition region and the anticipated halogen content. The retention ratios were $94 \%$ for $\mathrm{F}, 58 \%$ for $\mathrm{Cl}$, and $\sim 20 \%$ for I. If I losses that occur before the melter feed is converted to glass were preventable, higher concentrations of I would probably be retained in waste glass. 


\section{Contents}

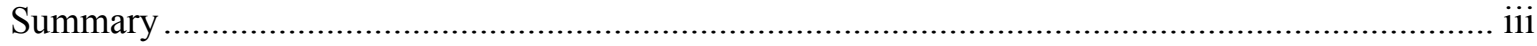

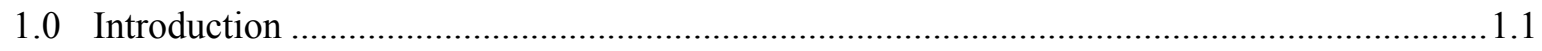

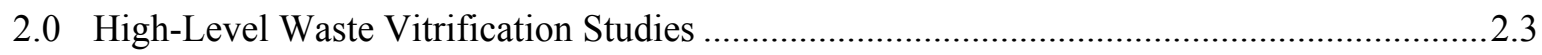

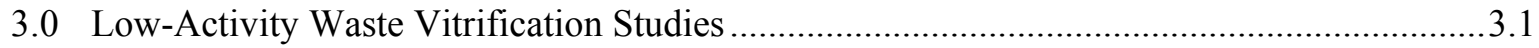

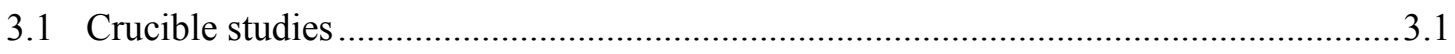

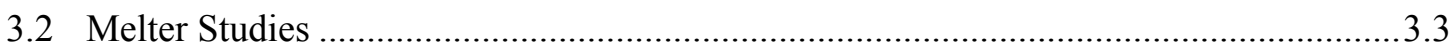

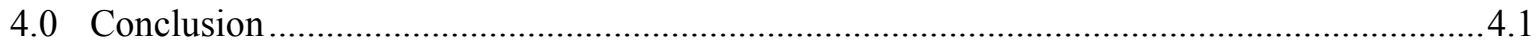

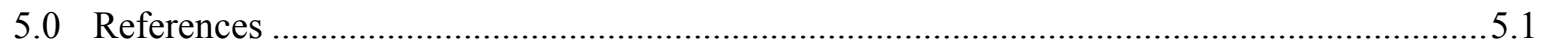

\section{Figures}

Figure 3.2. Chlorine Retention in Crucible Tests .........................................................................

Figure 3.3. Retention of Halogens in DuraMelter 100 Tests ....................................................... 3.6

Figure 3.4. Iodine Retention Versus $\mathrm{Na}_{2} \mathrm{O}$ Content in Glass ........................................................

Figure 3.5. Chlorine Retention Versus Bubbling Rate ............................................................ 3.8

Figure 3.6. Halogen Retention Ration Versus Ionic Radius and Sodium Halide Melting Point ....3.9

Figure 3.7. Retention of I in DuraMelter 100 Tests, Offgas Data ...............................................10

Figure 3.8.Halogen Retention Ration Versus Ionic Radius for Various Melter Technologies and Two

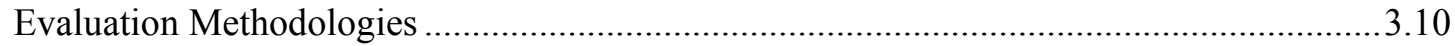

\section{Tables}

Table 2.1. Retention Data for Halogens from a Pilot-Scale Melter Experiment ...........................2.3

Table 2.2. Retention Ratios for Halogens Based on Offgas Data ..............................................2.4

Table 2.3. Retention Ratios for Halogens Based on Glass Analysis ...........................................2.4

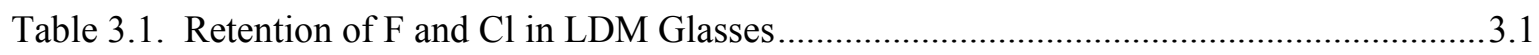

Table 3.2.Rates of Volatilization and Solubility Limits of F and Cl in Glass L6-5412, Data by Li (1995)3.2

Table 3.3. Retention Ratios for LAW Glass Processed with Different Technologies ....................3.3

Table 3.4. Retention Data for $\mathrm{Cl}$ and I, Crucible Test Results ( $g_{i}$ values are in mass \%) ................3.3

Table 3.5. Retention Data for $\mathrm{Cl}$ and I, DuraMelter 100 Test Results (all $g_{i}$ values are in mass\%)3.4

Table 3.6. Retention Ratios Based on DuraMelter 100 Test Offgas Data ......................................6

Table 3.7. Effect of Rate of Bubbling on Cl Retention for LAW A1 Sub-Envelope ...................... 3.8

Table 3.8. .... DuraMelter 100 Retention Rates, Ionic Radii $(r)$, and NaX Melting Temperatures $\left(T_{m}\right) \quad 3.9$ 


\subsection{Introduction}

Of five halogens ( $\mathrm{F}, \mathrm{Cl}, \mathrm{Br}, \mathrm{I}$, and At), only $\mathrm{F}$ was thoroughly explored in connection with commercial glass making. Some attention was also paid to $\mathrm{Cl}$ because $\mathrm{NaCl}$ is a fining agent. Volf (1984) only briefly mentions additions of bromides and iodides that can also function as fining agents. Additionally, halogens accelerate batch melting reactions.

Although additions of halides to nuclear waste feeds were briefly considered as melt-rate accelerators and foam breakers, halogens are generally viewed as troublesome components. Typical nuclear waste feeds contain up to $10 \mathrm{~g}$ of $\mathrm{F}$ and $4 \mathrm{~g}$ of $\mathrm{Cl}$ per $\mathrm{kg}$ of glass. The fractions of $\mathrm{Br}$ and $\mathrm{I}$ are even smaller, $\leq 100 \mathrm{mg}$ per $\mathrm{kg}$ of glass. When halogens are present in nuclear wastes, the main concern is their volatility because halogen-containing fumes and particulates are hazardous. Moreover, ${ }^{129} \mathrm{I}$ is a radioactive isotope with a $1.7 \times 10^{7}$-year half life.

Commercial glass experience shows that $\mathrm{F}$ and $\mathrm{Cl}$ are soluble in oxide glasses to a limited extent. Because their solubility decreases as the melt temperature decreases, fluorides and chlorides tend to precipitate on cooling, producing opacity. Consequently, $\mathrm{F}$ and $\mathrm{Cl}$ can be retained in the waste glass in the form of a dissolved constituent or as a dispersed crystalline phase.

The response of halogens to waste glass processing is evaluated differently by materials scientists and by chemical engineers. Materials scientists are concerned with the glass product in terms of its chemical and phase composition, whereas chemical engineers are interested in the efficiency of melters and offgas equipment in removing halogens from liquid and gaseous streams into solid phases.

Materials scientists examine the effect of glass composition and the method of glass preparation on halogen retention with the aim to maximize the $i$-th halogen retention ratio, $R_{i}$, defined as

$$
R_{i}=\frac{g_{i r}}{g_{i 0}}
$$

where $g_{i 0}$ is the $i$-th halogen nominal (or target) mass fraction in glass (the mass fraction if $i$-th halogen that would be present in glass if the total amount added with the feed were retained), and $g_{i r}$ is the $i$-th halogen mass fraction in glass actually retained (as determined by chemical analysis of glass).

Since $g_{i 0} \geq g_{i r}$, then $R_{i} \leq 1$. The difference between $g_{i 0}$ and $g_{i r}$ is caused by losses to the atmosphere due to volatility. Values of $R_{i} \geq 1$ indicate an analytical error, either of the waste or of the glass; analytical errors are likely to occur in determining extremely minute concentrations, such as those of I in glass.

Chemical engineers view a glass melter as a reactor to which feed continuously enters and from which two streams exit, namely, molten glass and offgas. The efficiency of trapping a contaminant component in glass is measured in terms of the $i$-th component decontamination factor, $D_{F i}$; defined as the ratio of the mass rate of flow of this component into the melter $\left(N_{0 i}\right)$ and its mass rate of flow in offgas exiting the melter $\left(N_{g i}\right)$. Hence, 


$$
D_{F i}=\frac{N_{0 i}}{N_{g i}}
$$

This definition makes sense only when a steady state is established, i.e., the streams are constant in magnitude and composition. Then $N_{0 i} \geq N_{g i}$, and thus $D_{F i} \geq 1$.

For a steady state, $N_{0 i}=g_{i 0} N_{G}$ and $N_{g i}=N_{0 i}-g_{i r} N_{G}$, where $N_{G}$ is the mass rate of flow of glass exiting the melter. Equation (1.2) can be expressed in the form

$$
D_{F i}=\frac{g_{i 0}}{g_{i 0}+g_{i r}}
$$

Then, by Equation (1.1), we obtain

$$
R_{i}=1-\frac{1}{D_{F i}}
$$

Equation (1.4) allows converting the $D_{F i}$ values, commonly reported in melter test protocols, to the retention ratios. In some reports, $D_{F i}$ values are determined from offgas data. The mass balance for an $i$-th contaminant can be written as

$$
g_{i 0}=g_{i r}+\sum_{j-1}^{K} g_{i j}+g_{i e}
$$

where $g_{i j}$ is the $i$-th component fraction trapped in $j$-th offgas equipment, $g_{i e}$ is the $i$-th component fraction that escaped undetected (the fractions are all related to the amount of glass produced), and $K$ is the number of offgas devices. Eliminating $g_{i r}$ from Equations (1.1) and (1.5) leads to the expression

$$
R_{i}=1-\sum_{1}^{K} \frac{g_{i j}}{g_{i 0}}-\frac{g_{i e}}{g_{i 0}}
$$

If glass analysis is not performed (or only electropositive elements are determined and halogens are ignored), $R_{i}$ can be obtained from Equation (1.6) provided that $g_{i e}<<g_{i 0}$. When the reported $D_{F i}$ values are determined from offgas data, it is important to check the overall mass balance of the contaminant to make certain that no unaccounted losses occurred, i.e., that indeed $g_{i e}<<g_{i 0}$.

The retention ratio of a component is different from its solubility limit. The solubility limit is defined as the fraction of component at a local equilibrium or with a gaseous atmosphere. However, the glassmaking process generally does not allow molten glass to reach equilibrium. While the portion of a component dissolved in the amorphous phase (or amorphous phases if phase separation occurs, e.g., in the presence of excess phosphates) may be undersaturated (i.e., below the solubility limit), a substantial portion may simultaneously exist in the form of inclusions (i.e., inhomogeneities). Therefore, the retention ratio is a dynamic quantity that depends on the glass-making conditions. 
Glass-making conditions are determined by melter design and operation. A high surface-to-volume ratio and extensive convection promote volatilization. Convection in the melter can be driven by buoyancy or surface forces (natural convection) or by stirring or bubbling (forced convection). The surface-to-volume ratio is influenced by the degree of melt surface coverage by the cold cap (unreacted feed) and by the degree of process stability (the frequency and length of idling periods). The extensive free melt surface greatly influences losses to offgas. Inclusions tend to segregate from molten glass during idling periods. For example, chlorides segregated to the melt surface readily evaporate. The rate of volatilization is affected by the furnace atmosphere, whether dry or humid, moving or stagnant. The mode of feed preparation is also important because halides can evaporate even from the feed before it is converted to glass.

The main objective of this report is to compile the known data regarding the retention of halogens, mainly I, in both high-level waste (HLW) and low-activity waste (LAW) glasses. The main focus is on I because of its radioactivity. Available data on $\mathrm{F}$ and $\mathrm{Cl}$ were compiled for comparison. Though $\mathrm{Br}$ is present in nuclear wastes, it is usually ignored; no data on $\mathrm{Br}$ retention were found. The following sections summarize retention data for Hanford HLW and LAW glasses processed in both laboratory crucibles and in pilot-scale melters.

\subsection{High-Level Waste Vitrification Studies}

Reporting on decontamination factors for halogens, including I, began in the 1980s, starting with the pilot-scale melter PSCM-22 (Perez and Nakaoka 1986). The melter vitrified a simulated HLW. The loading fraction of waste in glass was 0.25 , the melt volume in the melter was $270 \mathrm{~L}$, the average melt temperature was $1150^{\circ} \mathrm{C}$, and the melter operated for $384 \mathrm{~h}$, producing $6.25 \mathrm{Mg}$ of glass. Table 2.1 shows the retention values for $\mathrm{F}, \mathrm{Cl}$, and $\mathrm{I}$. The $g_{i 0}$ values were calculated from the waste composition and the waste loading based on an unpublished report compiled by Nakaoka (see the Table 2.1 footnote). Perez and Nakaoka (1986) list $D_{F i}$ values for individual glass components. The $R_{i}$ values were calculated using Equation (1.4), and the $g_{i r}$ values were back-calculated using Equation (1.1).

Table 2.1. Retention Data for Halogens from a Pilot-Scale Melter Experiment (PSCM-22)

\begin{tabular}{|c|c|c|c|c|}
\hline & $g_{i 0}$ & $g_{i r}$ & $D_{F i}$ & $R_{i}$ \\
\hline$F^{(a)}$ & 0.0475 & 0.0327 & 3.2 & 0.69 \\
\hline $\mathrm{Cl}^{(\mathrm{a})(\mathrm{b})}$ & 0.0250 & 0.0058 & 1.3 & 0.23 \\
\hline I & 0.0025 & 0.0006 & 1.3 & 0.23 \\
\hline 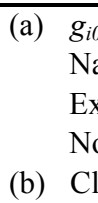 & \multicolumn{4}{|c|}{$\begin{array}{l}g_{i 0} \text { values for the Reference Feed as reported in } \\
\text { Nakaoka et al. (1985). Pilot-Scale Ceramic Melter } \\
\text { Experiment, HWVP-86-V1124A, Pacific } \\
\text { Northwest Laboratory, Richland, Washington. } \\
\mathrm{Cl} \text { was present in } \mathrm{Fe}_{2} \mathrm{O}_{3} \text { as an } \mathrm{FeCl}_{3} \text { impurity. }\end{array}$} \\
\hline
\end{tabular}

Decontamination factors as recorded in various melter testing reports are summarized in Table 2.2. With the exception of PSCM-22, no I data were obtained for the melter experiments listed in Table 2.2. The $R_{i}$ values were obtained from the reported $D_{F i}$ values using Equation (4). The $D_{F i}$ values themselves were estimated from offgas analyses assuming zero undetected amounts of halogens. 
Table 2.2. Retention Ratios for Halogens Based on Offgas Data

\begin{tabular}{llll}
\hline & F & Cl & Report \\
\hline LFCM-8 & 0.75 & 0.75 & Perez et at. (1994a) \\
PSCM-22 & 0.69 & 0.23 & Perez and Nakaoka (1986) \\
PSCM-23 & 0.89 & 0.85 & Goles et al. (1990) \\
SSHTM-3 $^{\text {(a) }}$ & 0.67 & 0.80 & Perez et at. (1994b) \\
\hline \multicolumn{2}{l}{ (a) Melter designed for LAW vitrification. } \\
\hline
\end{tabular}

As Table 2.2 shows, the $\mathrm{F}$ retention was relatively stable at $75 \pm 9 \%$, whereas the $\mathrm{Cl}$ retention varied widely from $23 \%$ to $85 \%$. However, the PDCM-22 test, in which only $23 \% \mathrm{Cl}$ was retained in glass, is exceptional in two ways: $\mathrm{Cl}$ was not an intentional waste component, but an impurity in $\mathrm{Fe}_{2} \mathrm{O}_{3}$, and the simulated waste was made of hydroxides instead of nitrates. It is possible that a large portion of $\mathrm{Cl}$ was lost from the unmelted hydroxide feed, whereas the nitrate feeds would preserve halides as dissolved components in molten nitrates. Nitrates begin to melt at temperatures as low as $300^{\circ} \mathrm{C}$ and are decomposed by $750^{\circ} \mathrm{C}$. It is likely that hydroxides are first converted to oxides that are later gradually incorporated into the alkali-borosilicate melt. This may occur at approximately $900^{\circ} \mathrm{C}$, thus giving halogens ample opportunity to escape. Apart from the difference between PSCM-22 and -23 melter experiments in the feed makeup, the PSCM-23 test had higher process stability, resulting from a better cold-cap behavior, and hence provided a smaller free surface for volatilization.

There are offgas data that may not provide precise retention values unless $g_{i e}<<g_{i l}$, i.e., when some vaporized halogens, especially I, remain unaccounted for. To obtain values based on chemical analysis of glass, Goles (1989) performed pyrohydrolytic-ion chromatographic (PIC) analysis of glass products generated in PSCM-22 and -23 melter experiments. In the PIC method, a glass powder was hydrolyzed in a stream of $\mathrm{Ar}(0.5 \mathrm{~L} / \mathrm{min})$ and $\mathrm{H}_{2} \mathrm{O}(1.5 \mathrm{~mL} / \mathrm{min})$ at $1200^{\circ} \mathrm{C}$. The halogens were trapped in an aqueous scrubber, and their concentrations were determined with ion chromatography. Table 2.3 lists the results. The $R_{\mathrm{Cl}}$ values are in good agreement with those estimated from offgas analyses (Table 2.2). The $R_{\mathrm{F}}$ values are in excellent agreement only for PSCM-23.

Table 2.3. Retention Ratios for Halogens Based on Glass Analysis

\begin{tabular}{llll}
\hline & \multicolumn{3}{c}{$R_{i}$} \\
\cline { 2 - 4 } & $\mathrm{F}$ & $\mathrm{Cl}$ & $\mathrm{I}$ \\
\hline PSCM-22 & 0.27 & 0.19 & 0.08 \\
PSCM-23 & 0.90 & 0.85 & \\
\hline
\end{tabular}




\subsection{Low-Activity Waste Vitrification Studies}

Because halides are water soluble, most of the halides from the waste partition to the LAW portion. Consequently, greater attention was paid to retention of halides, especially I, in LAW glasses. Both crucible studies were performed, and melter tests were carefully evaluated with respect to their halogen retention efficiency.

\subsection{Crucible studies}

Feng et al. (1996) performed crucible studies of S, P, F, and Cl retention in six LAW glasses. Concentrations of halogens in glass were measured by X-ray fluorescence (XRF) analysis. All glasses had the same nominal mass fractions of halogens: $g_{\mathrm{F} 0}=0.0082, g_{\mathrm{Cl} 0}=0.0064$, and $g_{\mathrm{I} 0}=0.0013$. The analyzed fractions and retention ratios for $\mathrm{F}$ and $\mathrm{Cl}$ are summarized in Table 3.1; no analysis was performed for I.

Table 3.1. Retention of $\mathrm{F}$ and $\mathrm{Cl}$ in LDM Glasses

\begin{tabular}{lc:ll|ll}
\hline & & \multicolumn{3}{|c|}{$\mathrm{F}$} & \multicolumn{2}{c}{$\mathrm{Cl}$} \\
\cline { 3 - 6 } Glass ID & $T_{M}{ }^{\circ} \mathrm{C}$ & $g_{\mathrm{Fr}}$ & $R_{\mathrm{F}}$ & $g_{\mathrm{C} r}$ & $R_{\mathrm{Cl}}$ \\
\hline LDM-0912 & 1381 & 0.0082 & 1.00 & 0.0030 & 0.47 \\
LDM-5412 & 1290 & 0.0099 & 1.21 & 0.0030 & 0.47 \\
LDM-1 & 1310 & 0.0070 & 0.85 & 0.0034 & 0.53 \\
LDM-2 & 1320 & 0.0089 & 1.09 & 0.0045 & 0.70 \\
LDM-3 & 1410 & 0.0063 & 0.77 & 0.0019 & 0.30 \\
LDM-4 & 1130 & 0.0113 & 1.38 & 0.0050 & 0.78
\end{tabular}

As Table 3.1 shows, all $\mathrm{F}$ was retained in four out of six glasses (values of $R_{i} \geq 1$ were caused by an analytical error). These four glasses contained 4 to $9 \% \mathrm{CaO}$. In glasses with a lower $\mathrm{CaO}$ content ( $2 \%$ LDM- 1 and $0 \%$ in LDM-3), only $85 \%$ and $77 \% \mathrm{~F}$ was retained. The retention of $\mathrm{Cl}$ was nearly half or the nominal value $\left(R_{\mathrm{Cl}}=0.49 \pm 0.18\right)$.

In a similar study, $\mathrm{Li}(1995)$ added $\mathrm{NaF}$ and $\mathrm{NaCl}$ to Glass L6-5412 and measured both the mass loss due to volatilization and the maximum concentrations of $\mathrm{F}$ and $\mathrm{Cl}$ that remained dissolved in the glass without residual microscopic inclusions. For each melt, the batch mass was $130 \mathrm{~g}$, and the melt surfaceto-volume ratio was $0.2 \mathrm{~mm}^{-1}$. The melting temperature varied from $1300^{\circ} \mathrm{C}$ to $1450^{\circ} \mathrm{C}$, and the dwell time was $2 \mathrm{~h}$.

The mass loss of glass spiked with $\mathrm{F}$ or $\mathrm{Cl}$ grew in proportion to the halogen fraction $\left(g_{i 0}\right)$. No attempt was made to determine the volatile species; they probably included halides and borates. Table 3.2 shows that the mass loss per halogen addition had a mild tendency to increase with increasing temperature.

Table 3.2 also shows the solubilities. At fractions above the solubility limit, the excess $\mathrm{F}$ formed $\mathrm{CaF}_{2}$ and $\mathrm{NaF}$ crystals. The excess $\mathrm{Cl}$ formed spherical $\mathrm{NaCl}$ inclusions (crystallized $\mathrm{NaCl}$ droplets). Solubilities were also measured for Glass L4-9012 treated at $1350^{\circ} \mathrm{C}$ for $2 \mathrm{~h}$. In this Ca-free glass, the dissolved fraction of $\mathrm{F}, 0.0132$, was limited by NaF solubility and was higher than in Glass L6-5412 containing 4 mass\% $\mathrm{CaO}$; the $\mathrm{Cl}$ solubility, 0.0049, was slightly lower than in Glass L6-5412. 
Table 3.2. Rates of Volatilization and Solubility Limits of $\mathrm{F}$ and $\mathrm{Cl}$ in Glass L6-5412, Data by Li (1995)

\begin{tabular}{c|cc|cc}
\hline & \multicolumn{2}{|c|}{$\begin{array}{c}\text { Mass Loss Rate } \\
\text { g glass/g X }\end{array}$} & \multicolumn{2}{c}{$\begin{array}{c}\text { Solubility Limit } \\
\mathrm{g} \mathrm{X} / \mathrm{g} \text { glass }\end{array}$} \\
\cline { 2 - 5 }$T_{M}\left({ }^{\circ} \mathrm{C}\right)$ & $\mathrm{F}$ & $\mathrm{Cl}$ & $\mathrm{F}$ & $\mathrm{Cl}$ \\
\hline 1300 & 0.7 & 1.6 & 0.0077 & 0.0056 \\
1350 & 0.8 & 1.8 & 0.0092 & 0.0057 \\
1400 & 0.8 & 2.0 & 0.0091 & 0.0052 \\
\hline \multicolumn{2}{l|l}{ X stands for halogen. } \\
\hline
\end{tabular}

In-depth studies of $\mathrm{F}, \mathrm{Cl}$, and I solubilities and volatilization were performed by Crichton et al. (1995a and 1995b). They used the same Glass L6-5412 as Li (1995). Unlike Li, who used XRF, they measured halogen concentrations in glass with scanning electron microscopy (SEM) energy-dispersive spectroscopy (EDS) analysis. The temperature varied from $1100^{\circ} \mathrm{C}$ to $1400^{\circ} \mathrm{C}$ and the dwell time was from $0.5 \mathrm{~h}$ to $2 \mathrm{~h}$.

The mass loss of glasses spiked with $\mathrm{F}$ was a parabolic function of time (i.e., the mass loss increased linearly with $t^{1 / 2}$ ) regardless of $\mathrm{F}$ concentration in the glass. A similar behavior was observed when glass was spiked with $\leq 1.2$ mass $\% \mathrm{Cl}$; at higher concentrations, the mass loss was initially a linear function of time, indicating evaporation of a segregated layer of molten $\mathrm{NaCl}$ on the glass melt surface. Almost all I was lost in $10 \mathrm{~min}$ at $1300^{\circ} \mathrm{C}$. The volatilization of I was observed at temperatures as low as $900^{\circ} \mathrm{C}$.

The maximum $\mathrm{F}$ addition that did not cause opalescence was 0.028 for glass melted at $1100^{\circ} \mathrm{C}$; the analyzed content, in mass fraction, was 0.0279 . This value is very much in excess of Li's result $(0.0077$ at $1300^{\circ} \mathrm{C}$ ) shown in Table 3.2, especially considering that the solubility limit for $\mathrm{F}$ decreases rather than increases with decreasing temperature. Because the analytical methods were different in each study and the rates of quenching have not been quantified, it is difficult to assess which value is more correct.

The maximum $\mathrm{Cl}$ addition, in mass fraction, that did not cause opalescence was 0.008 . The measured fraction was 0.0066, a value comparable with Li's data shown in Table 3.2. The difference in the added and retained $\mathrm{Cl}$ was attributed to volatilization.

The maximum I addition, in mass fraction, that did not cause gaseous $\mathrm{I}_{2}$ to form bubbles was 0.0002 . Interestingly, the SEM-EDS-measured fraction of I in glass with I bubbles was 0.0050 near the bubbles and 0.0082 in the bulk glass, indicating that 0.8 mass \% I could dissolve in glass. However, this oversaturated concentration decayed, by evaporation, to $0.02 \mathrm{mass} \%$.

Crichton et al. (1995a and 1995b) observed a remarkable difference in the modes of transport of halogens from glass to the atmosphere. As mentioned above, $\mathrm{F}$ evaporates from the melt surface, whereas $\mathrm{Cl}$, apart from direct volatilization, is separated into liquid $\mathrm{NaCl}$ inclusions that rise to the melt surface by buoyancy where they make a segregated evaporating layer. Finally, I creates $\mathrm{I}_{2}$ bubbles that rise to the melt surface where they burst.

However, halides may evaporate even before the batch is converted to glass. This is least likely for fluorides; $\mathrm{NaF}$ melts at $996^{\circ} \mathrm{C}$ and thus, assuming that glass melt becomes connected at a temperature around $900^{\circ} \mathrm{C}$, all $\mathrm{F}$ is likely to be incorporated into glass. $\mathrm{NaCl}$ is more likely to evaporate from the batch 
because $\mathrm{NaCl}$ melts at $801^{\circ} \mathrm{C}$. Finally, NaI, melting at $660^{\circ} \mathrm{C}$, is most likely to begin to vaporize before its incorporation in the glass melt.

The low retention of I in glass can be attributed to its evaporation from the unmelted batch and its low solubility in glass. Even though iodides may be preserved as minor components in the nitrate melt until the glass-forming melt becomes connected and the partial pressure of $I_{2}$ in gas bubbles may be high, a large portion of I is likely to escape from batch regardless of the processing method.

\subsection{Melter Studies}

Various technologies were tested to process glasses that incorporated simulated LAW in a series of pilot-scale experiments. Volatilities of feed components were measured and reported by Whyatt et al. (1996). To determine volatility losses more accurately, the authors corrected the measured $g_{i r}$ values by multiplying them by a factor determined from the nominal-to-measured ratio of an abundant non-volatile component, such as $\mathrm{SiO}_{2}$. Table 3.3 presents the results.

Table 3.3. Retention Ratios for LAW Glass Processed with Different Technologies

\begin{tabular}{llccc}
\hline Melter & Feed & F & Cl & I \\
\hline Low-temperature, Inconel electrodes & Slurry & 0.47 & 0.52 & 0.18 \\
High-temperature, Mo electrodes & Slurry & 0.85 & 0.36 & 0.17 \\
High-temperature, Mo electrodes & Pellets & 0.99 & 0.93 & 0.90 \\
Carbon-electrodes & Calcine & 0.09 & 0.18 & 0.05 \\
Plasma torch-fired cupola & Slurry & 0.09 & 0.12 & 0.02 \\
Gas-fired cyclone combustion & Slurry & 0.08 & 0.13 & 0.06 \\
\hline
\end{tabular}

Based on these data, one can estimate that about $20 \%$ of I is retained in the glass processed by feeding a slurry into a continuous Joule-heated melter. The data show that I retention is lower than $\mathrm{Cl}$ retention $(1 / 3$ to $1 / 2$ for slurry-fed Joule-heated melters). Note the remarkable high retentions of halides in the wetted pellet-fed high-temperature continuous electric melter (the melter was designed and operated by Envitco, Inc., a company based in Toledo, Ohio).

Matlack et al. (2002a-d, 2003a and 2003b) and André (2003) reported a wealth of data on the retention of halogens in glass for both laboratory crucibles and a pilot-scale melter. The melter (DuraMelter 100) contains 115 to $120 \mathrm{~kg}$ of glass, the melt surface area is $0.108 \mathrm{~m}^{2}$, and the average melt temperature is $1150^{\circ} \mathrm{C}$.

The results for halogen retention are summarized in Table 3.4 through Table 3.7 and Figure 3.1 through Figure 3.4. Retention ratios listed in Table 3.4 and Table 3.5 were determined from glass analyses, and those listed in Table 3.6 were obtained from offgas data.

Table 3.4. Retention Data for $\mathrm{Cl}$ and $\mathrm{I}$, Crucible Test Results ( $g_{i}$ values are in mass\%)

\begin{tabular}{llcccccc}
\hline Report No. & Test & $g_{\mathrm{Cl} 0}$ & $g_{\mathrm{Clr}}$ & $R_{\mathrm{Cl}}$ & $g_{\mathrm{I} 0}$ & $g_{\mathrm{I} r}$ & $R_{\mathrm{I}}$ \\
\hline \multirow{2}{*}{ VSL-02R62N0-1 } & LAW A3-1 & 0.30 & 0.11 & 0.37 & NA & NA & NA \\
& LAW A3-2 & 0.37 & 0.04 & 0.11 & NA & NA & NA
\end{tabular}




\begin{tabular}{llcccccc}
\hline Report No. & Test & $g_{\mathrm{Cl} 0}$ & $g_{\mathrm{Clr}}$ & $R_{\mathrm{Cl}}$ & $g_{\mathrm{I} 0}$ & $g_{\mathrm{I}}$ & $R_{\mathrm{I}}$ \\
\hline & LAW A3-3 & 0.33 & 0.10 & 0.29 & NA & NA & NA \\
\hline \multirow{4}{*}{ VSL-02R62N0-2 } & LAW C1-1 & 0.07 & 0.04 & 0.61 & NA & NA & NA \\
& LAW C1-2 & 0.09 & 0.02 & 0.27 & NA & NA & NA \\
& LAW C1-3 & 0.09 & 0.02 & 0.18 & NA & NA & NA \\
\hline \multirow{2}{*}{ VSL-02R62N0-3 } & LAW A2(-15\%) & 0.11 & 0.05 & 0.45 & 0.10 & 0.01 & 0.10 \\
& LAW A2(+15\%) & 0.14 & 0.06 & 0.43 & 0.10 & 0.01 & 0.10 \\
& LAW A2 & 0.13 & 0.03 & 0.23 & 0.10 & 0.01 & 0.10 \\
\hline \multirow{2}{*}{ VSL-02R62N0-4 } & LAW A1(-15\%) & 0.49 & 0.21 & 0.43 & 0.10 & 0.02 & 0.20 \\
& LAW A1(+15\%) & 0.62 & 0.13 & 0.21 & 0.10 & 0.01 & 0.10 \\
\hline \multirow{2}{*}{ VSL-02R62N0-6 } & LAW C1 & 0.14 & 0.04 & 0.29 & 0.10 & $<0.01$ & $<0.10$ \\
& LAW A1 & 1.17 & 0.46 & 0.39 & 0.10 & 0.02 & 0.20 \\
\hline \multirow{2}{*}{ VSL-03R3410-1 } & LAW A2 & 0.42 & 0.06 & 0.14 & 0.10 & 0.01 & 0.10 \\
& LAW B1 & 0.02 & 0.02 & 1.00 & 0.10 & 0.00 & 0.00 \\
\hline Average & & & & 0.36 & & & 0.11 \\
\hline NA: not analyzed & & & & & & \\
\hline
\end{tabular}

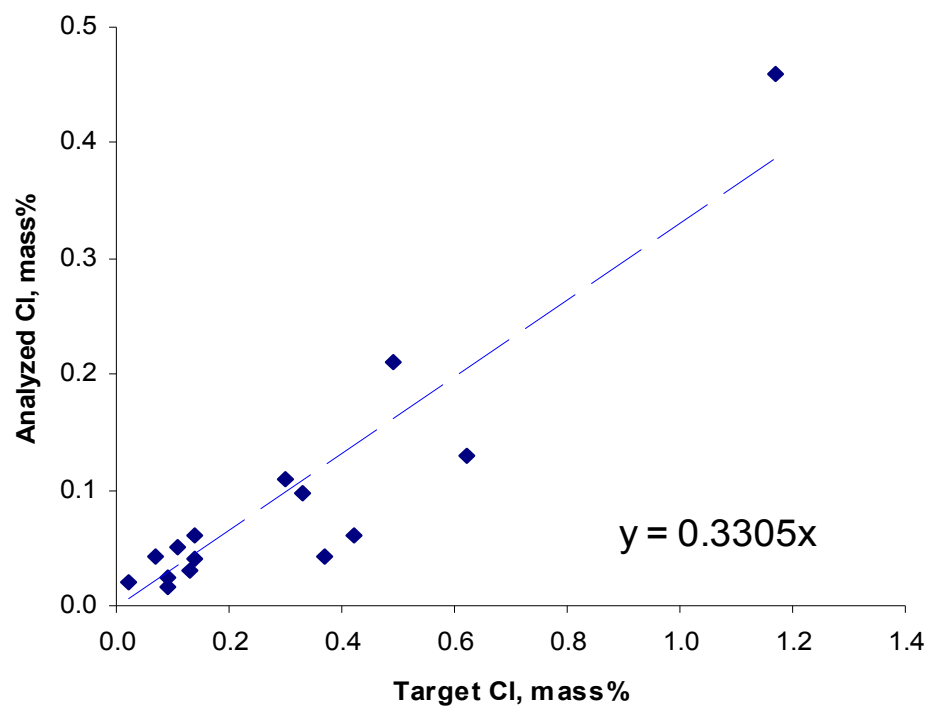

Figure 3.1. Chlorine Retention in Crucible Tests

As Table 3.4 and Figure 3.1 show, crucible melts retained $1 / 3$ of $\mathrm{Cl}$ and $10-20 \%$ of I. These retention values were lower than those achieved in the melter. According to Table 3.5 and Figure 3.2, the $\mathrm{Cl}$ retention in the melter was $\sim 60 \%$ and I retention was $\sim 20 \%$. The larger volatilization losses of halogens from laboratory crucible melts can be attributed to their high surface-to-volume ratios.

Table 3.5. Retention Data for $\mathrm{Cl}$ and I, DuraMelter 100 Test Results (all $g_{i}$ values are in mass\%)

\begin{tabular}{|c|c|c|c|c|c|c|c|}
\hline Report No. & Test & $g_{\mathrm{Cl} 10}$ & $g_{\mathrm{Clr}}$ & $R_{\mathrm{Cl}}$ & $g_{\mathrm{I} 0}$ & $g_{\mathrm{I} r}$ & $R_{\mathrm{I}}$ \\
\hline \multirow{3}{*}{ VSL-02R62N0-1 ${ }^{\text {(a) }}$} & LAW A3-1 & 0.30 & 0.21 & 0.69 & $\mathrm{NA}$ & $\mathrm{NA}$ & NA \\
\hline & LAW A3-2 & 0.37 & 0.24 & 0.65 & NA & NA & NA \\
\hline & LAW A3-3 ${ }^{(b)}$ & 0.33 & 0.21 & 0.63 & NA & NA & NA \\
\hline VSL-02R62N0-2 $2^{(\mathrm{c})}$ & LAW C1-1 & 0.07 & 0.04 & 0.63 & NA & NA & NA \\
\hline
\end{tabular}




\begin{tabular}{|c|c|c|c|c|c|c|c|}
\hline Report No. & Test & $g_{\mathrm{Cl} 1}$ & $g_{\mathrm{Clr}}$ & $R_{\mathrm{Cl}}$ & $g_{\mathrm{I} 0}$ & $g_{\mathrm{I} r}$ & $R_{\mathrm{I}}$ \\
\hline & LAW C1-2 & 0.09 & 0.06 & 0.67 & NA & NA & $\overline{\mathrm{NA}}$ \\
\hline & LAW C1-3 & 0.09 & 0.06 & 0.70 & NA & NA & NA \\
\hline \multirow{3}{*}{ VSL-02R62N0-3(d) } & LAW A2(-15\%) & 0.11 & 0.07 & 0.64 & 0.10 & 0.02 & 0.20 \\
\hline & LAW A2(+15\%) & 0.14 & 0.07 & 0.50 & 0.10 & 0.02 & 0.20 \\
\hline & LAW A2 & 0.13 & 0.07 & 0.54 & 0.10 & 0.01 & 0.10 \\
\hline \multirow{2}{*}{ VSL-02R62N0-4(e) } & LAW A1(-15\%) & 0.49 & 0.28 & 0.57 & 0.10 & 0.04 & 0.40 \\
\hline & LAW A1(+15\%) & 0.62 & 0.34 & 0.55 & 0.10 & 0.02 & 0.20 \\
\hline \multirow{2}{*}{ VSL-02R62N0-6 ${ }^{(\mathrm{f})}$} & LAW C1 & 0.14 & 0.09 & 0.64 & 0.10 & $<0.01$ & $<0.10$ \\
\hline & LAW A1 & 1.17 & 0.67 & 0.57 & 0.10 & 0.03 & 0.30 \\
\hline \multirow{2}{*}{ VSL-03R3410-1 ${ }^{(\mathrm{g})}$} & LAW A2 & 0.42 & 0.24 & 0.57 & 0.10 & 0.03 & 0.30 \\
\hline & LAW B1 & 0.02 & 0.02 & 1.00 & 0.10 & 0.01 & 0.10 \\
\hline \multicolumn{4}{|l|}{ Average } & 0.64 & & & 0.23 \\
\hline \multicolumn{4}{|l|}{ St. Deviation } & 0.12 & & & 0.10 \\
\hline 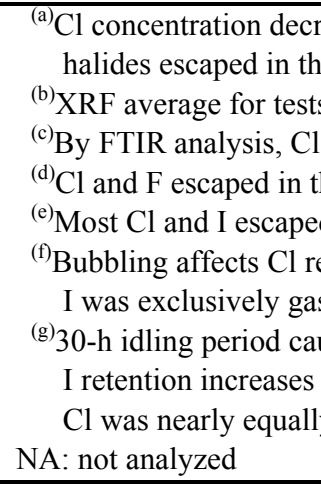 & $\begin{array}{l}\text { ed during idling and in } \\
\text { orm of gas. } \\
3 \text { and 3C. } \\
\text { d F escaped in the form } \\
\text { form of particulates, I in } \\
\text { the form of particulate } \\
\text { tion; see Table 3.7. Cl } \\
\text { us. } \\
\text { d a dip in Cl concentrat } \\
h \text { alkali content; } \\
\text { ivided between gas and }\end{array}$ & $\begin{array}{l}\text { IF and } \\
\text { form o } \\
\text { trappec } \\
\text { from } 0 \\
\text { iculate }\end{array}$ & $\begin{array}{l}\text { g subsec } \\
\text { Cl; I in t } \\
\text { gas. } \\
\text { s partice } \\
5 \text { to } 0.16 \\
\text { nissions }\end{array}$ & $\begin{array}{l}\text { ent con } \\
\text { e form } \\
\text { ate emi } \\
\text { o); }\end{array}$ & $\begin{array}{l}\text { nuous p } \\
\text { gas. } \\
\text { ion; }\end{array}$ & ocessing; & gaseous \\
\hline
\end{tabular}

Figure 3.2 compares glass analysis data with offgas data. Only offgas-based data are available for F (Figure 3.2a). Their scatter is low, and the F retention is consistently high (94\%), regardless of glass composition and the targeted $\mathrm{F}$ content.

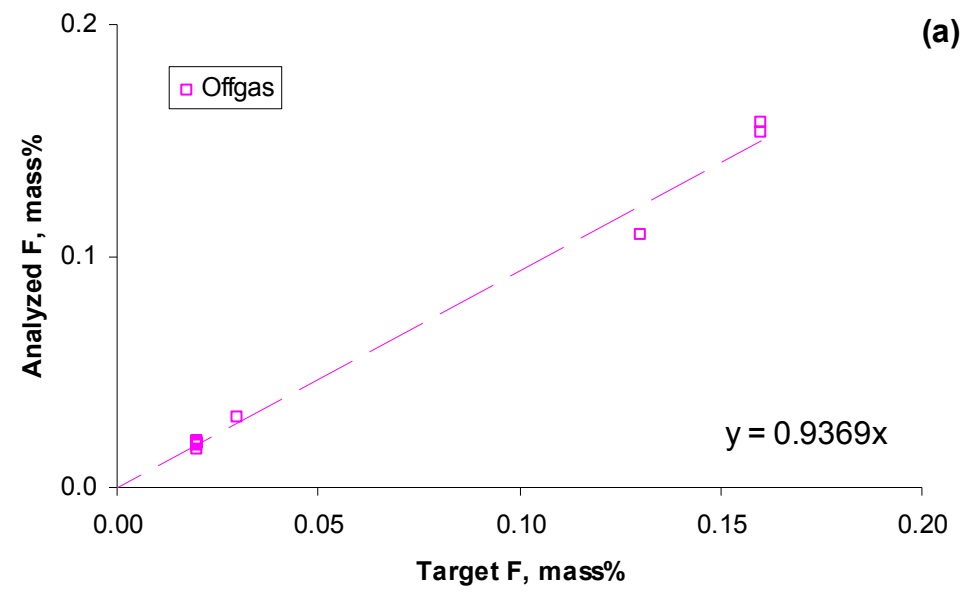



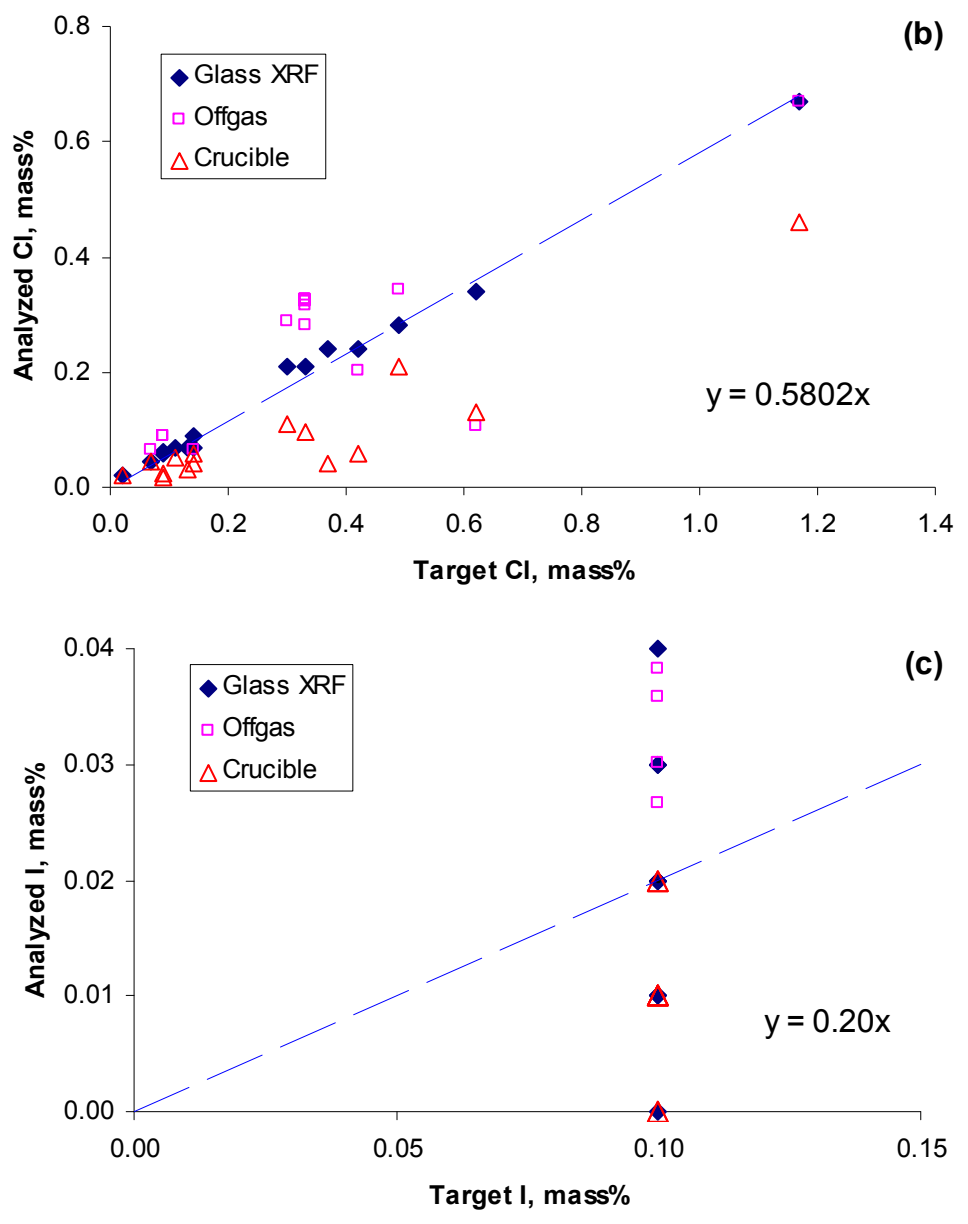

Figure 3.2. Retention of Halogens in DuraMelter 100 Tests

The plot of $g_{\mathrm{Cl} r}$ versus $g_{\mathrm{Cl} 0}$ values (Figure 3.2b) shows little scatter for glass analysis-based data. The trendline through these data indicates that $58 \%$ of $\mathrm{Cl}$ was retained in glass regardless of composition variation (for example, $\mathrm{Na}_{2} \mathrm{O}$ content varied from 6 mass $\%$ to 21 mass $\%$ ) and regardless of the targeted $\mathrm{Cl}$ content. The scatter of offgas-based data is large, but the data points are well distributed around the trendline representing the glass analysis-based results. The crucible $\mathrm{Cl}$ retention data, apart from having low values, are also widely scattered. The average retention ratio for $\mathrm{Cl}$ is $64 \%$, based on glass analysis (Table 3.5), and 79\%, based on offgas analysis (Table 3.6).

The target fraction $\left(g_{\mathrm{I} O}\right)$ of I was 0.1 mass $\%$ for all tests. As Figure $3.2 \mathrm{c}$ shows, I retention data are widely scattered. The trendline in Figure 3.2c indicates $20 \%$ retention for glass analysis; the average value (Table 3.5 ) is $23 \%$. The wide scatter of the results is caused by the very low $g_{\text {Ir }}$ values $(<0.01-0.04$ mass $\%$ of I in glass). Offgas data indicate an apparent higher I retention (49\%), but these high values are misleading because a fraction of I escaped detection (the I mass balance did not come up to $100 \%$ ).

Table 3.6. Retention Ratios Based on DuraMelter 100 Test Offgas Data 


\begin{tabular}{|c|c|c|c|c|}
\hline & Test & $\mathrm{F}$ & $\mathrm{Cl}$ & $\mathrm{I}$ \\
\hline \multirow{6}{*}{ VSL-02R62N0-1 } & LAW A3-1 & 0.84 & 0.96 & 0.44 \\
\hline & LAW A3-2 & 1.00 & NA & 0.41 \\
\hline & LAW A3-3A & 0.91 & 0.98 & 0.23 \\
\hline & LAW A3-3B & 0.98 & 0.99 & 0.82 \\
\hline & LAW A3-3C & 0.94 & 0.96 & 0.41 \\
\hline & LAW A3-3D & 0.98 & 0.98 & 0.85 \\
\hline \multirow{3}{*}{ VSL-02R62N0-2 } & LAW C1-1 & 0.84 & 0.91 & 0.23 \\
\hline & LAW C1-2 & 0.98 & 1.00 & 0.60 \\
\hline & LAW C1-3 & 0.96 & 1.00 & 0.38 \\
\hline \multirow{2}{*}{ VSL-02R62N0-4 } & LAW A1(-15\%) & NA & 0.70 & 0.84 \\
\hline & LAW A1(+15\%) & NA & 0.17 & 0.38 \\
\hline \multirow{2}{*}{ VSL-02R62N0-6 } & LAW C1 & NA & 0.46 & 0.30 \\
\hline & LAW A1 & $\mathrm{NA}$ & 0.57 & 0.27 \\
\hline \multirow{2}{*}{ VSL-03R3410-1 } & LAW A2 & NA & 0.48 & 0.36 \\
\hline & LAW B1 & NA & 0.00 & 0.00 \\
\hline TRP-PLT-062 $2^{(\mathrm{a})}$ & LAW A1 & 0.96 & 0.85 & 0.84 \\
\hline Average & & 0.94 & 0.79 & 0.49 \\
\hline St. deviation & & 0.06 & 0.27 & 0.24 \\
\hline
\end{tabular}

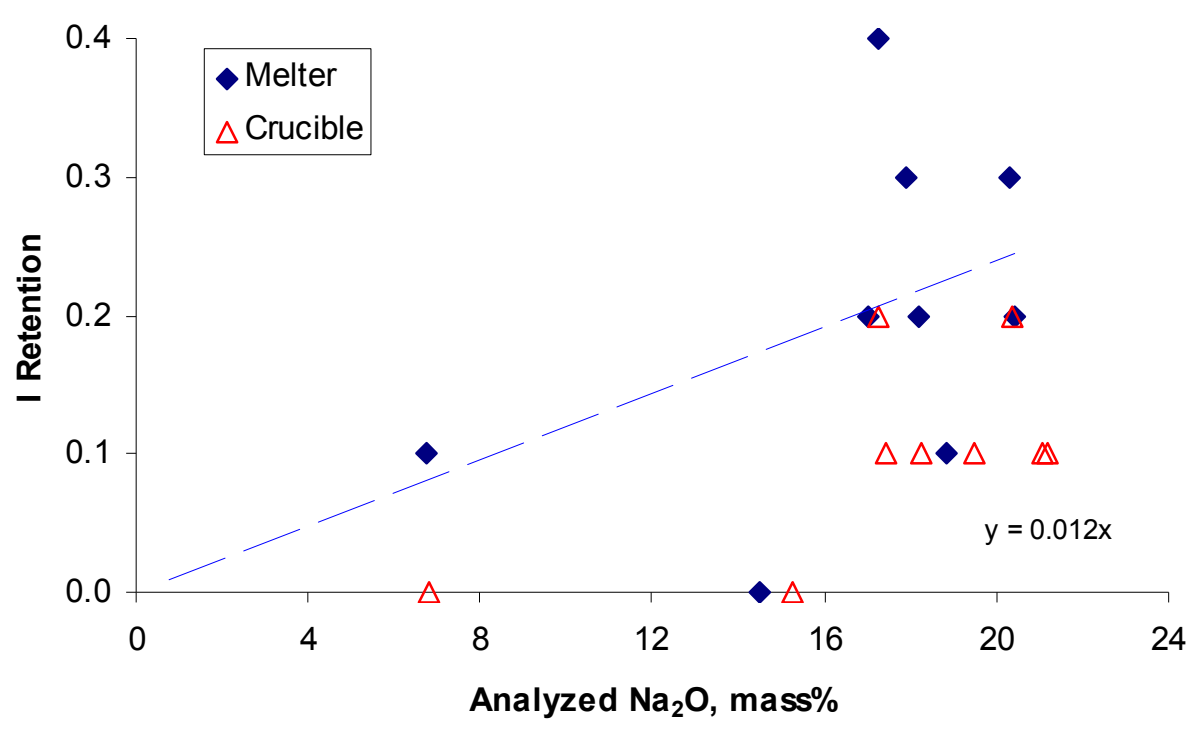

Figure 3.3. Iodine Retention Versus $\mathrm{Na}_{2} \mathrm{O}$ Content in Glass

Other variables that affect the retention of halogens are glass composition, temperature, time, and bubbling. The retention of I can also be affected by glass redox because, as Crichton et al. (1995a and $1995 b$ ) observed, $\mathrm{I}$ is released in the form of $\mathrm{I}_{2}$ vapors. 
As Figure 3.2 indicates, glass composition did not affect $\mathrm{F}$ and $\mathrm{Cl}$ retention, at least within the LAW composition region. Regarding I, Matlack et al. (2002a-d, 2003a and 2003b) claim that I retention increases with increasing content of alkalis in the glass. This conclusion is based on one data point measured for a glass containing 6 mass $\% \mathrm{Na}_{2} \mathrm{O}$. As Figure 3.3 shows, evidence for such a conclusion is weak.

Because the glass processing temperature was $\sim 150^{\circ} \mathrm{C}$, nearly constant for all tests, its effect on halogen retention was not observed. However, the impact of time was evidenced in sharp decreases in $\mathrm{Cl}$ concentration in glass after the melter was idled; for example, 2-month idling resulted in a decrease of $\mathrm{Cl}$ mass fraction from 0.0022 to 0.0009 , indicating that tiny $\mathrm{NaCl}$ inclusions had enough time to ascend to the melt surface where they evaporated.

In a test with varying rates of bubbling, the $\mathrm{Cl}$ retention showed a tendency to decrease as the bubbling rate increased (Table 3.7). The trendline in Figure 3.4 shows that the $\mathrm{Cl}$ retention decreased by approximately $1 \%$ when the rate of bubbling increased by $1 \mathrm{~L} / \mathrm{min}$.

Table 3.7. Effect of Rate of Bubbling on Cl Retention for LAW A1 Sub-Envelope

\begin{tabular}{ccc}
\hline $\begin{array}{c}\text { Bubbling } \\
\text { L/min }\end{array}$ & $g_{i r}$ & $R$ \\
\hline 1.9 & 0.94 & 0.80 \\
\hline 9.0 & 0.67 & 0.57 \\
16.0 & 0.76 & 0.65 \\
\hline
\end{tabular}

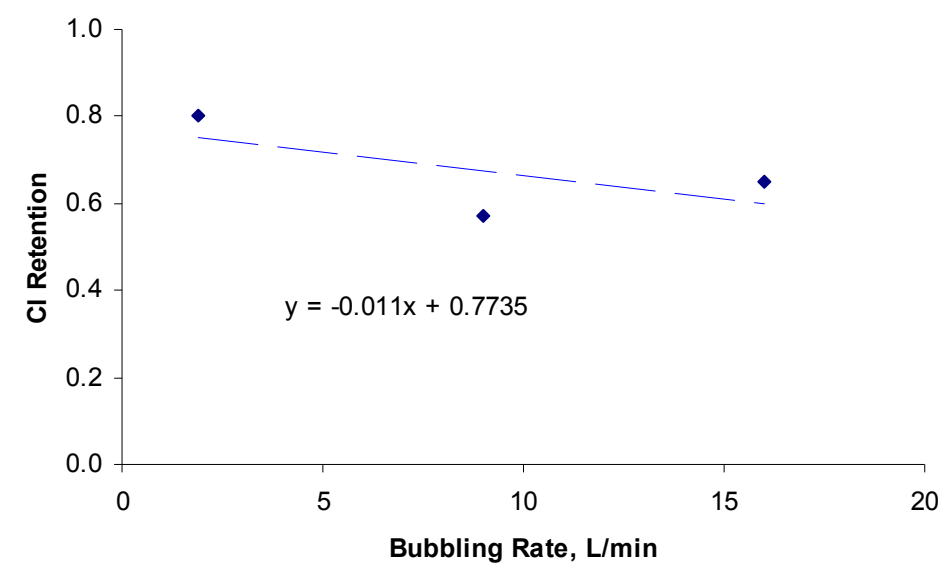

Figure 3.4. Chlorine Retention Versus Bubbling Rate

The oxidation of $\mathrm{I}^{-}$to $\mathrm{I}_{2}$ can proceed as the a reaction with $\mathrm{Fe}(\mathrm{III})$ as follows:

$$
2 \mathrm{NaI}+\mathrm{Fe}_{2} \mathrm{O}_{3}=\mathrm{I}_{2}+2 \mathrm{FeO}+\mathrm{Na}_{2} \mathrm{O}
$$


According to this reaction, reduced glass promotes I retention. Unfortunately, there are not enough data to support this hypothesis. In tests reported by Matlack et al. (2002a-d, 2003a and 2003b), glasses were either oxidized ( $\mathrm{Fe}(\mathrm{II}) / \mathrm{Fe}<0.008$, where 0.008 is the detection limit for the colorimetric method used) or, in a series of tests where $\mathrm{Fe}(\mathrm{II}) / \mathrm{Fe}$ was increased up to 0.645 , I concentration was not measured (Matlack et al. 2002a). The only exception is test LAW A1(-15\%) reported in Matlack et al. (2002d) where $\mathrm{Fe}(\mathrm{II}) / \mathrm{Fe}=0.06$. As Table 3.5 shows, the I retention for this reduced glass was the highest based on glass analysis data (0.4); according to Table 3.6, the offgas-based retention value was also one of the highest (0.84).

The retention ratios indicated by the slopes of the trendlines in Figure 3.2 represent normal conditions of melter operation and are based on a large number of data. Therefore, they should be considered representative for the behavior of halides in DuraMelter 100. These characteristic retention ratios are summarized in Table 3.8. They were plotted against halogen ionic radii and sodium halide melting temperatures in Figure 3.5. The relatively good linear correlation allowed estimating a retention ratio for $\mathrm{Br}$ by interpolation. Its value, shown in Table 3.8, indicates that $42 \% \mathrm{Br}$ can be retained in glass processed in DuraMelter 100.

Table 3.8. DuraMelter 100 Retention Rates, Ionic Radii $(r)$, and NaX Melting Temperatures $\left(T_{m}\right)$

\begin{tabular}{lllr}
\hline & $R_{i}$ & $r, \mathrm{~nm}$ & $T_{m},{ }^{\circ} \mathrm{C}$ \\
\hline $\mathrm{F}$ & 0.9396 & 0.133 & 996 \\
$\mathrm{Cl}$ & 0.5802 & 0.181 & 801 \\
$\mathrm{Br}$ & 0.4209 & 0.220 & 660 \\
$\mathrm{I}$ & 0.2000 & 0.196 & 747 \\
\hline
\end{tabular}
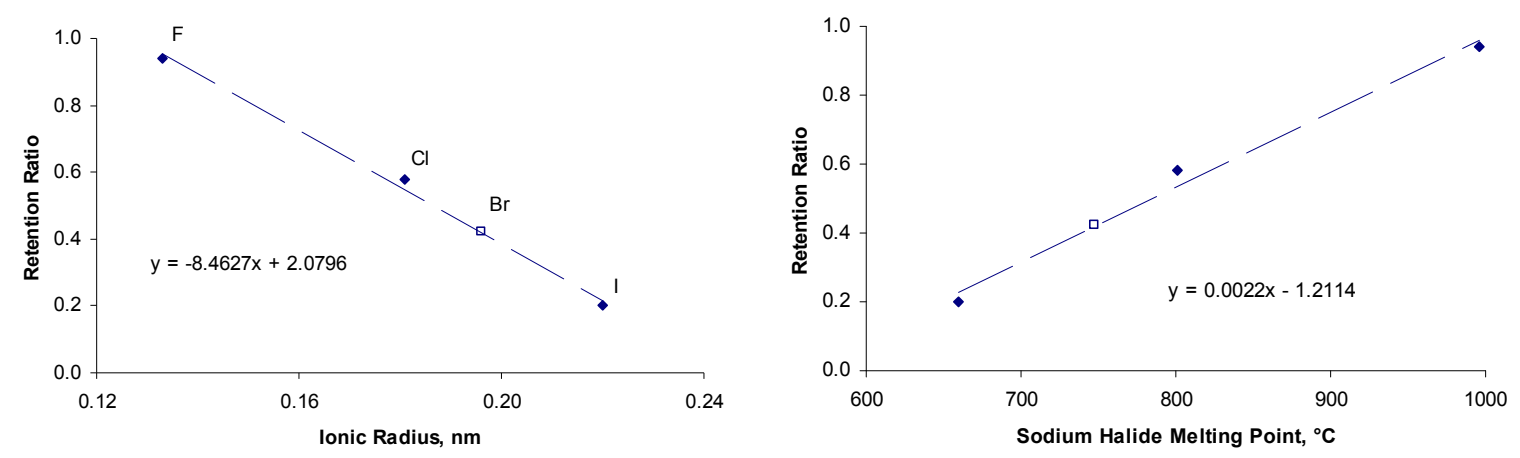

Figure 3.5. Halogen Retention Ration Versus Ionic Radius and Sodium Halide Melting Point

The correlation between $R_{i}$ and the ionic radius can be fortuitous. First, as Crichton et al. (1995a and 1995b) observed, the mechanism of liberation from glass is different for the three halogens $(\mathrm{F}, \mathrm{Cl}$, and I) for which data are available. Second, data for $\mathrm{F}$ are based on offgas measurements, whereas data for $\mathrm{Cl}$ and I are based on glass analysis. These data may not be comparable because offgas data plus glass analysis data rarely recover $100 \%$ of halogens. Finally, I data are subjected to an extremely high scatter. The I retention values based on glass analysis vary between 0.1 and $0.4(0.23 \pm 0.10$ on average; see Table 3.5), and the values based on offgas measurements vary between 0 and $0.85(0.49 \pm 0.24$ on average; 
see Table 3.6). The offgas data for I are shown in Figure 3.6 where the value measured for the reduced glass (with $\mathrm{Fe}(\mathrm{II}) / \mathrm{Fe}=0.06$ ) is represented by a large full square.

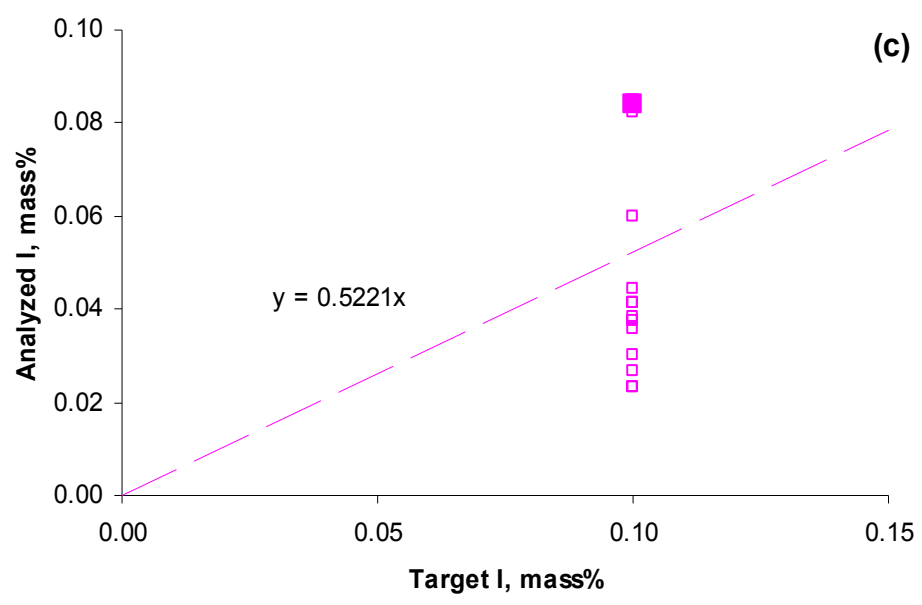

Figure 3.6. Retention of I in DuraMelter 100 Tests, Offgas Data

Provided that the correlation between halogen retention and ionic radius (or a similar property, such as alkali halide melting point) is real, we can expect that this correlation would strongly depend on the vitrification technology used. As Figure 3.7 shows, Envitko achieved a very low decrease of retention with increasing ionic radius.

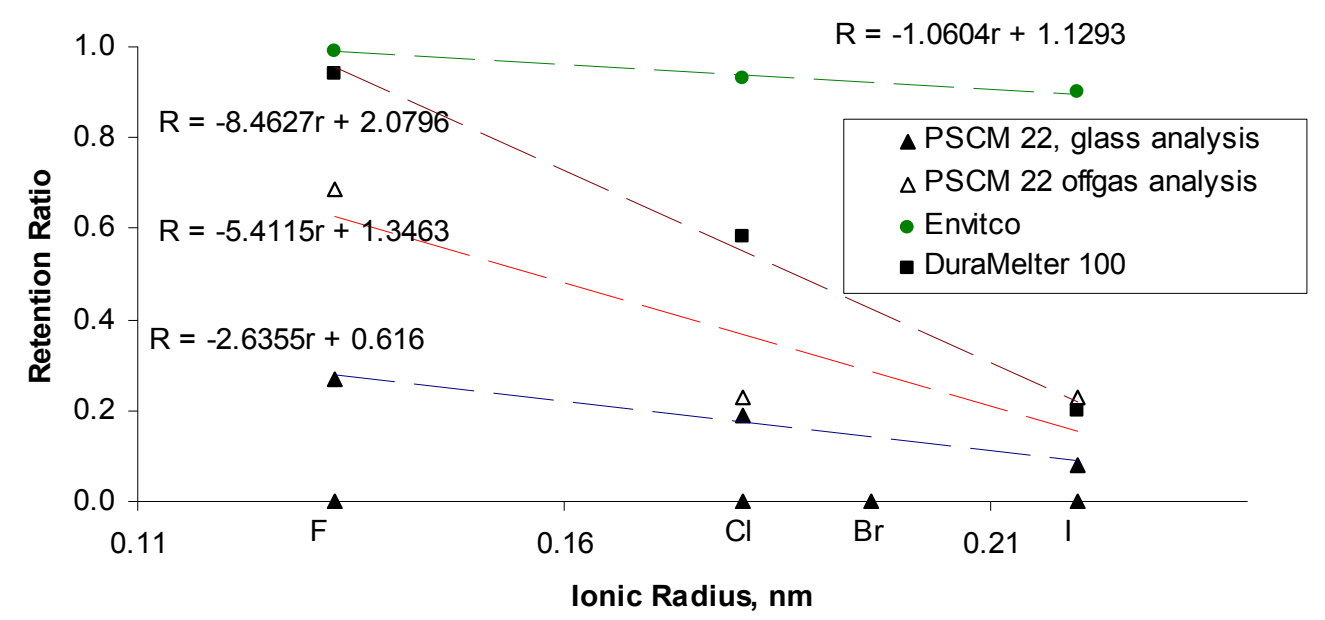

Figure 3.7. Halogen Retention Ration Versus Ionic Radius for Various Melter Technologies and Two Evaluation Methodologies 


\subsection{Conclusion}

Neither crucible studies nor the early melter experiments appear representative for the retention of halogens in waste glasses expected during the normal mode of operation of a continuous electric melter. Fortunately, tests conducted with DuraMelter 100 present consistent data showing that the halogen retention ratio based on glass analyses varied little with glass composition within the LAW composition region. This ratio was independent of the halogen content in the waste feed, at least up to $0.2 \mathrm{mass} \% \mathrm{~F}$ and 1.5 mass $\% \mathrm{Cl}$ (these mass \% values are based on the glass produced). Only feeds with a single value of 0.1 mass $\%$ I were processed. The retention ratios, as based on XRF glass analysis, were $94 \%$ for $\mathrm{F}$, $58 \%$ for $\mathrm{Cl}$, and $\sim 20 \%$ for I ( $42 \%$ was an estimated retention for $\mathrm{Br}$ ).

The retention of $\mathrm{I}$ is subjected to a large uncertainty and may be underestimated because:

- A very high I retention value obtained in the wetted pellet-fed high-temperature continuous electric melter (0.9) indicates that I retention can be substantially increased.

- The offgas data suggest that the actual I retention could be $50 \%$ or higher (provided that XRF analysis underestimated I concentration in glass).

- The I retention value of $20 \%$, though consistent with historical data, is subjected to a large error $( \pm 10 \%)$ that can be decreased when more accurate analytical methods are applied and a better inventory of I is achieved for the melter system.

The retention ratio appeared to decrease linearly with the halogen ionic radius. The slope of this plot was different for different vitrification technologies. A very low slope was achieved by the Envitco system where 90 mass\% of I was retained in glass. Crucible studies also indicate that high I retention is realistic because most of the I losses seem to occur before the melter feed is converted to glass. If these losses were prevented and molten salt segregation was avoided, a higher amount of I would be retained in waste glass. 


\subsection{References}

André, L. 2003. RPP-WTP Pilot Melter Envelope A Melter Emissions Test Results Report, TRR-PLT062, Duratek, Inc., Columbia, MD.

Crichton, S.N., T.J. Barbieri, and M. Tomozawa. 1995a. "Solubility Limits for Troublesome Components in a Simulated Low Level Waste Glass," Environmental Issues and Waste Management Technologies in the Ceramic and Nuclear Industries (Ed. V. Jain and R. Palmer), Ceramic Transactions, Vol. 61, p. 283-290.

Crichton, S.N., T.J. Barbieri, and M. Tomozawa. 1995b. "Volatilization Rates of Troublesome Components from a Simulated Low Level Nuclear Waste Glass," Environmental Issues and Waste Management Technologies in the Ceramic and Nuclear Industries (Ed. V. Jain and R. Palmer), Ceramic Transactions, Vol. 61, p. 291-298.

Feng, X., M.J. Schweiger, H. Li, and M. Gong. 1996. Retention of Sulfur, Phosphorus, Chlorine, and Fluorine in Hanford Phase II Vendor LLW Glasses," Proceedings of the International Topical Meeting on Nuclear and Hazardous Waste Management Spectrum '96, p. 555-562, American Nuclear Society, La Gland Park, Illinois.

Goles, R.W. 1989. Determination of Halogen Content in Glass for Assessment of Melter Decontamination Factors, HWVP-89-IVJ0020500D, Pacific Northwest Laboratory, Richland, Washington.

Goles, R.W., R.K. Nakaoka, J.M. Perez, G.J. Sevigny, S.O. Bates, M.R. Elmore, D.E. Larson, K.D. Wiemers, M.E. Peterson, C.M. Andersen, W.C. Buchmiller, and C.M. Ruecker. 1990. Hanford Waste Vitrification Program Pilot Scale Ceramic Melter Test 23, PNL-7142 UC-721, Pacific Northwest Laboratory, Richland, Washington.

Li, H. 1995. Data Package of Minor Component Study for Low-Level Nuclear Waste Glass, PVTD C9502.01B, Pacific Northwest Laboratory, Richland, Washington.

Matlack, K.S., W. Gong, and I.L. Pegg. 2002a. Compositional Variation Tests on DuraMelter 100 with LAW Sub-Envelope A3 Feed in Support of the LAW Pilot Melter, VSL-01R62N0-1, Vitreous State Laboratory, The Catholic University of America, Washington DC.

Matlack, K.S., W. Gong, and I.L. Pegg. 2002b. Compositional Variation Tests on DuraMelter 100 with LAW Sub-Envelope C1 Feed (LAWC22 Glass) in Support of the LAW Pilot Melter, VSL-02R62N0-2, Vitreous State Laboratory, The Catholic University of America, Washington DC.

Matlack, K.S., W. Gong, and I.L. Pegg. 2002c. Compositional Variation Tests on DuraMelter 100 with LAW Sub-Envelope A2 Feed (LAWA88 Glass) in Support of the LAW Pilot Melter, VSL-02R62N0-3, Vitreous State Laboratory, The Catholic University of America, Washington DC. 
Matlack, K.S., W. Gong, and I.L. Pegg. 2002d. Compositional Variation Tests on DuraMelter 100 with Sub-Envelope A1 Feed (LAWA44 Glass) in Support of the LAW Pilot Melter, VSL-02R62N0-4, Vitreous State Laboratory, The Catholic University of America, Washington DC.

Matlack, K.S., W. Gong, and I.L. Pegg. 2003a. DuraMelter 100 Sub-Envelope Changeover Testing Using LAW Sub-Envelopes A1 and C1 Feeds in Support of the LAW Pilot Melter, VSL-02R62N0-6, Vitreous State Laboratory, The Catholic University of America, Washington DC.

Matlack, K.S., W. Gong, and I.L. Pegg. 2003b. DuraMelter 100 Sub-Envelope Changeover Testing Using LAW Sub-Envelope A2 and B1 Feeds in Support of the LAW Pilot Melter, VSL-03R3410-1, Vitreous State Laboratory, The Catholic University of America, Washington DC.

Perez Jr., J.M. and R.W. Nakaoka. 1986. "Vitrification Testing of Simulated High-Level Radioactive Waste from Hanford," Waste Management 1986 (Ed. By R.G. Post) Proceedings of the Symposium in Waste Management at Tucson, AZ, Vol. 2, pp. 495-505.

Perez J.M., Whitney L.D., Buchmiller W.C., Daume J.T., and Whyatt G.A. 1994a. HWVP Pilot-Scale Vitrification System Campaign - LFCM-8 Summary Report. PNNL-11096. PHTD-93-04.15DK963. Pacific Northwest Laboratory, Richland, Washington.

Perez, J.M., P.J. Shafer, and W.C. Buchmiller. 1994b. Test Results of Vitrifying TWRS DSSF LowLevel Waste Simulant; Small-Scale, High-Temperature Melter Test 3 (SSHTM-3), PVTD-C95-03.01A, Pacific Northwest Laboratory, Richland, Washington.

Volf, M.B. 1984. Chemical Approach to Glass, Elsevier, Amsterdam.

Whyatt, W.A., J.W. Shade, and G.E. Steegen. 1996. „Volatility and Entrainment of Feed Components and Product Glass Characteristics During Pilot-Scale Vitrification of Simulated Hanford Site Low-Level Waste," Proceedings of the International Topical Meeting on Nuclear and Hazardous Waste Management Spectrum '96, p. 555-584-593, American Nuclear Society, La Gland Park, Illinois. 



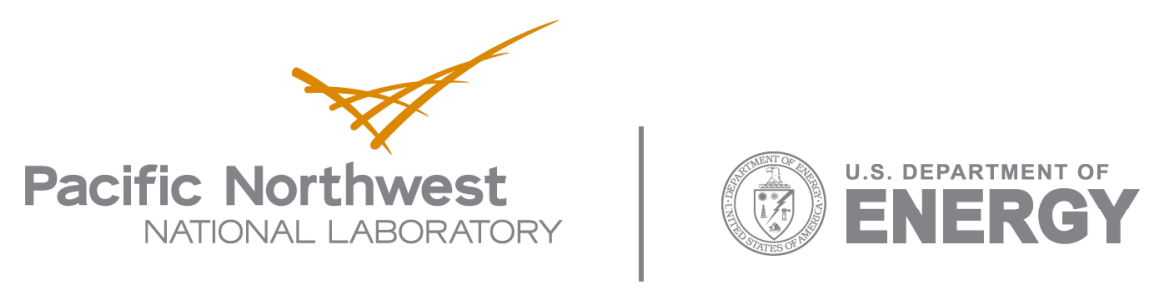

902 Battelle Boulevard

P.O. Box 999

Richland, WA 99352

1-888-375-PNNL (7665)

www.pnl.gov 